\title{
Effect of cumulative fertilizer dressings on the phosphorus status of mineral soils I Changes in inorganic phosphorus fractions
}

\author{
HELINÄ HARTIKAINEN \\ Department of Agricultural Chemistry, University of Helsinki, \\ SF-00710 Helsinki, Finland
}

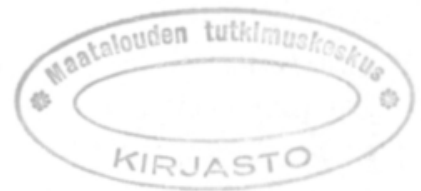

\begin{abstract}
Surface soil samples were collected from $16 \mathrm{P}$ fertilization trials before onset of the experiments and after seven years of cultivation. The changes in the inorganic $\mathrm{P}$ fractions were investigated in plots amended annually with 0,30 or $60 \mathrm{~kg}$ of $\mathrm{P} \mathrm{ha}^{-1}$. In the clay soils, cultivation without $\mathrm{P}$ fertilization depleted the $\mathrm{NH}_{4} \mathrm{~F}$-extractable and $\mathrm{NaOH}$-extractable $\mathrm{P}$ reserves by $22-69 \mathrm{~kg} \mathrm{ha}^{-1}$; in the coarser soils, the respective depletion was $8-140 \mathrm{~kg}$ $\mathrm{ha}^{-1} . \mathrm{H}_{2} \mathrm{SO}_{4}$-soluble $\mathrm{P}$ decreased in seven soils by $16-34 \mathrm{~kg} \mathrm{ha}^{-1}$. In the plots amended totally with 210 or $420 \mathrm{~kg}$ of $\mathrm{P} \mathrm{ha}^{-1}$, on the other hand, these $\mathrm{P}$ fractions increased by $24-174$ and $46-368 \mathrm{~kg} \mathrm{ha}^{-1}$, respectively. The higher the $\mathrm{P}$ dressing was, the more the added $\mathrm{P}$ tended to accumulate in the fluoride-soluble form as compared to the alkali-soluble form.
\end{abstract}

Index words: $\mathrm{P}$ accumulation, residual $\mathrm{P}$, inorganic $\mathrm{P}$ fractions

\section{Introduction}

Effective $\mathrm{P}$ sorption by $\mathrm{Al}$ and $\mathrm{Fe}$ compounds is typical of Finnish mineral soils (Kaila 1963, 1964, 1965, Hartikainen 1979). Efficient retention restricts losses by leaching, but also diminishes the availability of $\mathrm{P}$ to plants. LATURI (1977) calculated that the annual uptake of added $\mathrm{P}$ by yields averages $30 \%$, but much lower estimations have been published recently (SAARELA and SipPOLA 1987). Thus, during recent decades, a successive build-up of residual $\mathrm{P}$ has taken place in Finnish cultivated soils amended with large quantities of fertilizer P.
The long-term effect of fertilization intensity on different inorganic $\mathrm{P}$ reserves has been studied only sparsely under field conditions in which management practices, particularly ploughing, cause dilution of residual $\mathrm{P}$ in the uppermost layers. Store dressing with rock phosphate has been found to result in a quite permanent $\mathrm{P}$ enrichment in acid-soluble form (see HĀNNINEN and KAILA 1960, KaILA 1969), whereas superphosphate has been demonstrated to accumulate in $\mathrm{NH}_{4} \mathrm{~F}$-soluble and $\mathrm{NaOH}$-soluble fractions (KaILA 1961). There are, however, no data available on the 
changes that occur in various $\mathrm{P}$ fractions in plots cultivated for several years without $\mathrm{P}$ fertilization. The present study reports the $\mathrm{P}$ accumulation found in a seven-year field experiment with increasing superphosphate treatments and the depletion in $\mathrm{P}$ reserves in plots that received no $\mathrm{P}$ fertilizers.

\section{Material and methods}

The soil samples were collected from $16 \mathrm{P}$ fertilization trials carried out by the Institute of Agricultural Chemistry and Physics, Agricultural Research Centre, at several research stations in Finland. The trials involved five treatments where the $\mathrm{P}$ quantity added annually varied from 0 to $60 \mathrm{~kg} \mathrm{ha}^{-1}$. The experimental crops were mainly cereals, but pea and grasses were also cultivated.

The fields were composed of four blocks, each of which contained all the treatments. Five of the fields represented clay soils $(>30 \%$ clay fraction $<2 \mu \mathrm{m}), 11$ being coarser mineral soils. Characteristics of the soils are given in Table 1. The particle-size composition of mineral material was determined according to the pipette method of

Table 1. Characteristics of soils at the beginning of the field trials.

\begin{tabular}{lrrrrrr}
\hline Locality & Clay & $\mathrm{pH}$ & $\begin{array}{c}\text { Org.C } \\
\%\end{array}$ & & & \multicolumn{2}{c}{$\mathrm{Fe}_{\mathrm{o}}$} & $\mathrm{Al}_{\mathrm{o}}$ \\
\cline { 6 - 7 } & & & \multicolumn{2}{c}{$\mathrm{mmol} / \mathrm{kg}$} \\
\hline Clay soils & & & & & \\
1 Mietoinen & 74 & 5.7 & 3.1 & 73 & 53 \\
2 Mietoinen & 35 & 4.9 & 2.9 & 85 & 34 \\
3 Mietoinen & 59 & 5.3 & 3.3 & 80 & 47 \\
4 Mouhijärvi & 33 & 5.6 & 3.8 & 62 & 64 \\
5 Mouhijärvi & 35 & 4.8 & 3.5 & 61 & 47 \\
Coarser soils & & & & & \\
6 Kokemäki & 25 & 5.0 & 10.0 & 97 & 94 \\
7 Pälkäne & 12 & 4.8 & 3.2 & 46 & 59 \\
8 Maaninka & 8 & 5.4 & 2.3 & 68 & 45 \\
9 Laukaa & 26 & 5.5 & 3.5 & 60 & 30 \\
10 Toholampi & 6 & 4.6 & 4.2 & 68 & 98 \\
11 Toholampi & 18 & 4.2 & 11.1 & 138 & 102 \\
12 Mikkeli & 3 & 4.8 & 6.2 & 25 & 152 \\
13 Mietoinen & 24 & 4.8 & 2.3 & 52 & 31 \\
14 Tohmajärvi & 5 & 4.9 & 4.5 & 56 & 133 \\
15 Ylistaro & 27 & 4.6 & 8.9 & 85 & 133 \\
16 Anjala & 25 & 5.4 & 12.6 & 45 & 93 \\
\hline
\end{tabular}

Elonen (1971), and the organic C content was measured by a modified Alten wet combustion method (Graham 1948). Aluminium $\left(\mathrm{Al}_{\mathrm{o}}\right)$ and iron $\left(\mathrm{Fe}_{\mathrm{o}}\right)$ were extracted with an acid ( $\mathrm{pH} 3.3$ ) $0.05 \mathrm{M} \mathrm{NH}_{4}$-oxalate solution at a soil to solution ratio of 1:20.

Before the start of the trial, a volume of soil was gathered from each experimental field, air-dried and used as a control sample. The other samples were taken at the end of the trial from plots fertilized for seven years with 0 , 30 or $60 \mathrm{~kg}$ of $\mathrm{P} \mathrm{ha}{ }^{-1}$ annually. Each of the air-dried and $2 \mathrm{~mm}$ sieved subsamples was analyzed separately for $\mathrm{pH}$ in a $1: 2.5(\mathrm{w} / \mathrm{v})$ $0.01 \mathrm{M} \mathrm{CaCl}_{2}$ suspension and for inorganic $\mathrm{P}$ fractions by a modified CHANG and JACKSON procedure (HARTIKAINEN 1979). The P concentration in the extracts was determined by the molybdenum blue-stannous chloride method of Kalla (1955).

\section{Results and discussion}

The inorganic $\mathrm{P}$ fractions in soils at the beginning of the trials and the changes that occurred during the seven-year period as a result of different fertilization backgrounds are shown in Table 2 . The results, given in $\mathrm{kg}$ $\mathrm{ha}^{-1}$ per plough layer of $0-20 \mathrm{~cm}$, were calculated by assuming the bulk density of soil to be $1 \mathrm{~kg} \mathrm{dm}^{-3}$. These are only rough estimates, because the sampling sites in the fields after the trials cannot exactly coincide with those before the experiments. Furthermore, owing to the great variation between the replicates, the changes in the $\mathrm{P}$ fractions, though great, were not always statistically significant. In the following, the uncertain changes were not included in the calculations.

Al-P and Fe-P in Table 2 refer to the $\mathrm{NH}_{4} \mathrm{~F}$-soluble and $\mathrm{NaOH}$-soluble fractions assumed to represent $\mathrm{P}$ mainly bound by hydrated $\mathrm{Al}$ and $\mathrm{Fe}$ oxides, respectively. Seven years of cultivation without $\mathrm{P}$ addition depleted these reserves by $2-15 \%$ in the clay soils and by $2-17 \%$ in the coarser soils. In absolute quantities, the reduction in the clay soils ranged from 22 to $69 \mathrm{~kg} \mathrm{ha}^{-1}$, in the 
Table 2. $\mathrm{P}$ fractions in experimental soils $\left(\mathrm{kg} \mathrm{ha}^{-1}\right)$ and the changes in them during seven years of cultivation.

\begin{tabular}{|c|c|c|c|c|c|}
\hline \multirow{2}{*}{ Soil } & \multirow{2}{*}{$\begin{array}{c}\text { P frac- } \\
\text { tion }\end{array}$} & \multirow{2}{*}{$\begin{array}{l}\text { Con- } \\
\text { trol }\end{array}$} & \multicolumn{3}{|c|}{$\begin{array}{c}\text { Changes in plots that received } \\
\text { totally } \mathrm{P} \mathrm{kg} \mathrm{ha-1}\end{array}$} \\
\hline & & & 0 & 210 & 420 \\
\hline \multirow[t]{3}{*}{1} & Al-P & 93 & $-23^{* *}$ & 0 & $43^{* *}$ \\
\hline & Fe-P & 388 & -8 & $37^{* *}$ & $79 * * *$ \\
\hline & Ca-P & 668 & $-21^{*}$ & $-18^{*}$ & 5 \\
\hline \multirow[t]{3}{*}{2} & Al-P & 198 & $-22^{*}$ & 10 & $42^{* * *}$ \\
\hline & Fe-P & 688 & -17 & 29 & $87^{* * *}$ \\
\hline & $\mathrm{Ca}-\mathrm{P}$ & 763 & -15 & -40 & -10 \\
\hline \multirow[t]{3}{*}{3} & $\mathrm{Al}-\mathrm{P}$ & 115 & $-15^{* *}$ & $42^{* * *}$ & $108^{* * *}$ \\
\hline & $\mathrm{Fe}-\mathrm{P}$ & 462 & $-22^{*}$ & $67 * *$ & $117^{* * *}$ \\
\hline & $\mathrm{Ca}-\mathrm{P}$ & 760 & $-21^{*}$ & $30^{* * *}$ & $57^{* * *}$ \\
\hline \multirow[t]{3}{*}{4} & Al-P & 297 & $-23^{*}$ & $33^{* *}$ & $97^{* * *}$ \\
\hline & Fe-P & 600 & -23 & 21 & $69^{* *}$ \\
\hline & Ca-P & 557 & -3 & 17 & 0 \\
\hline \multirow[t]{3}{*}{5} & Al-P & 110 & $-27 * *$ & 10 & $42^{* * *}$ \\
\hline & Fe-P & 342 & $-42^{* * *}$ & -4 & $33^{*}$ \\
\hline & $\mathrm{Ca}-\mathrm{P}$ & 297 & $-27^{*}$ & -4 & 13 \\
\hline \multirow[t]{3}{*}{6} & $\mathrm{Al}-\mathrm{P}$ & 372 & -4 & $24^{*}$ & $98^{* *}$ \\
\hline & Fe-P & 670 & $-62^{*}$ & -10 & -16 \\
\hline & $\mathrm{Ca}-\mathrm{P}$ & 596 & 10 & -20 & -12 \\
\hline \multirow[t]{3}{*}{7} & Al-P & 118 & $-8^{*}$ & $38^{* *}$ & $76^{* * *}$ \\
\hline & Fe-P & 254 & -12 & 8 & $20^{*}$ \\
\hline & Ca-P & 320 & -32 & $-24^{*}$ & -14 \\
\hline \multirow[t]{3}{*}{8} & Al-P & 274 & $-50^{* * *}$ & $40^{* *}$ & $150^{* * *}$ \\
\hline & Fe-P & 544 & $-56^{* *}$ & 2 & 22 \\
\hline & Ca-P & 2240 & -24 & -6 & 60 \\
\hline \multirow[t]{3}{*}{9} & $\mathrm{Al}-\mathrm{P}$ & 264 & 0 & $56^{* *}$ & $100^{* * *}$ \\
\hline & Fe-P & 424 & 22 & 14 & $44^{*}$ \\
\hline & $\mathrm{Ca}-\mathrm{P}$ & 946 & $28^{*}$ & $34^{* * *}$ & $26^{* *}$ \\
\hline \multirow[t]{3}{*}{10} & Al-P & 210 & $-38^{*}$ & $30^{*}$ & $116^{* * * *}$ \\
\hline & Fe-P & 246 & $-32^{*}$ & 8 & $54^{* * *}$ \\
\hline & $\mathrm{Ca}-\mathrm{P}$ & 220 & $-16^{*}$ & 0 & 4 \\
\hline \multirow[t]{3}{*}{11} & Al-P & 256 & -16 & $60^{*}$ & $154^{* * * *}$ \\
\hline & Fe-P & 858 & $-54^{*}$ & $114^{* * *}$ & $214^{* * *}$ \\
\hline & $\mathrm{Ca}-\mathrm{P}$ & 324 & $-34^{*}$ & -16 & -30 \\
\hline \multirow[t]{3}{*}{12} & Al-P & 656 & $-86^{*}$ & $58^{*}$ & $46^{*}$ \\
\hline & Fe-P & 112 & -16 & 12 & -2 \\
\hline & Ca-P & 194 & $-22^{*}$ & 0 & $20^{*}$ \\
\hline \multirow[t]{3}{*}{13} & Al-P & 110 & $-20^{*}$ & 0 & $74^{* * *}$ \\
\hline & $\mathrm{Fe}-\mathrm{P}$ & 380 & $-42^{* *}$ & 4 & 20 \\
\hline & Ca-P & 728 & -10 & -12 & 12 \\
\hline \multirow[t]{3}{*}{14} & Al-P & 364 & $-78^{* * *}$ & -14 & $46^{* * *}$ \\
\hline & Fe-P & 404 & $46^{* *}$ & -6 & 6 \\
\hline & Ca-P & 302 & $-28^{*}$ & -6 & $-12^{*}$ \\
\hline \multirow[t]{3}{*}{15} & Al-P & 310 & $-96^{* * *}$ & 0 & -10 \\
\hline & $\mathrm{Fe}-\mathrm{P}$ & 522 & $-44^{*}$ & $24^{*}$ & $72 * *$ \\
\hline & Ca-P & 594 & -36 & -16 & -14 \\
\hline \multirow[t]{3}{*}{16} & Al-P & 390 & $-70^{* *}$ & $34^{*}$ & $112^{* * *}$ \\
\hline & Fe-P & 198 & $-8^{*}$ & 10 & $52^{* * *}$ \\
\hline & $\mathrm{Ca}-\mathrm{P}$ & 352 & -6 & 0 & -8 \\
\hline
\end{tabular}

* $=$ differs from the control at $\mathrm{P}=0.05$

$* *=n " n$ at $\mathrm{P}=0.01$

$* * *=n \quad " \quad n \quad$ at $\mathrm{P}=0.001$ coarser soils from 8 to $140 \mathrm{~kg} \mathrm{ha}^{-1}$, the average being 35 and $74 \mathrm{~kg} \mathrm{ha}^{-1}$, respectively. The $\mathrm{H}_{2} \mathrm{SO}_{4}$-soluble fraction, denoted as Ca-P in Table 2, decreased significantly in seven soils, the depletion being $16-34 \mathrm{~kg} \mathrm{ha}^{-1}$. The slight increase in these reserves found in soil 9 may be attributable to inaccuracies in sampling.

It is noteworthy that in soil 8 , the acidsoluble fraction was $2-10$ fold higher than in the other soils, and remained unaffected by the fertilization regimens. Heavy dressings with rock phosphate may result in marked increases in $\mathrm{H}_{2} \mathrm{SO}_{4}-\mathrm{P}$ (cf. KaILA 1969), but according to the information available at the Maaninka research station, no store dressing has been performed during past decades (K. RINNE oral communication, 19 Oct., 1988). On the other hand, the experimental field is located near the region where apatite is mined. Therefore it is likely that the high acid-soluble fraction was derived from native apatite reserves of the soil material. In acid Finnish soils, the $\mathrm{H}_{2} \mathrm{SO}_{4}$-soluble fraction is considered to represent mainly primary apatitic $\mathrm{P}$ (KaIla 1964), even though in soils treated with $\mathrm{P}$ fertilizers the acid extractant may also dissolve secondary $\mathrm{Ca}$ phosphates (KAILA 1961). In studies where $P$ is added e.g. as a $\mathrm{K}$ compound, this fraction has, however, been found to be quite inactive (KAILA 1964, HARTIKAINEN 1979).

The $\mathrm{P}$ fertilization increased the $\mathrm{NH}_{4} \mathrm{~F}$ soluble and $\mathrm{NaOH}$-soluble reserves in all but four soils, for which no significant changes in these fractions were observed. The recovery of fertilizer $\mathrm{P}$ amounted to $11-83 \%$ and $11-88 \%$ of the total $P$ additions of 210 and $420 \mathrm{~kg} \mathrm{ha}^{-1}$, respectively. The accumulation in the $\mathrm{Al}$ and $\mathrm{Fe}$ bound forms was highest in the very acid soil $11\left(\mathrm{pH}\right.$ in $\left.\mathrm{CaCl}_{2} 4.2\right)$ rich in oxalate-soluble $\mathrm{Fe}$. In the untreated control samples, the ratio of $\mathrm{NH}_{4} \mathrm{~F}-\mathrm{P}$ to $\mathrm{NaOH}-\mathrm{P}$ correlated moderately with the ratio of $\mathrm{Al}_{\mathrm{o}}$ to $\mathrm{Fe}_{\mathrm{o}}$, the value of $\mathrm{r}$ being $0.75^{* * *}(\mathrm{n}=15)$. When soil 12 , which was very high in $\mathrm{Al}_{\mathrm{o}}$, was included, the $\mathrm{r}$ value rose to $0.96^{* * * *}$. Nevertheless, the paired t-statistics revealed 
that in the soils amended with the lower $\mathrm{P}$ quantity, the $\mathrm{NH}_{4} \mathrm{~F}-\mathrm{P} / \mathrm{NaOH}-\mathrm{P}$ ratio was significantly higher than in the control samples, but lower than in the soils treated with heavy $\mathrm{P}$ dressings. This finding indicates that the higher the $\mathrm{P}$ dressing was, the more intensively the added $\mathrm{P}$ tended to accumulate in the fluoride-soluble fraction.

The acid-soluble P seemed to increase only in soils 3, 9 and 12. This does not mean, however, that no accumulation of fertilizer $\mathrm{P}$ as $\mathrm{Ca}$ compounds took place in other soils. KAILA (1961) demonstrated that in soils recently dressed with superphosphate, dicalcium phosphate, a reaction product of monocalcium phosphate, may be attacked by the $\mathrm{NH}_{4} \mathrm{~F}$ extractant in the earlier phase of the fractionation procedure.

\section{References}

Elonen, P. 1971. Particle-size analysis of soil. Acta Agr. Fenn. 122: 1-122.

Graham, E. 1948. Determination of soil organic matter by means of a photoelectric colorimeter. Soil Sci. 65 : 181-183.

Hartikainen, H. 1979. Phosphorus and its reactions in terrestrial soils and lake sediments. J. Scient. Agric. Soc. Finl. 51: 537-624.

Hanninen, P. \& Kaila, A. 1960. Field trials on the store dressing with rock phosphate. J. Scient. Agric. Soc. Finl. 32: 107-117.

JaAkKola, A., Syvallahtı, J. \& SaARı, E. 1982. Contents of mineral elements in Finnish cereal straw. J. Scient. Agric. Soc. Finl. 54: 385-394.

KAILA, A. 1955. Studies on the colorimetric determination of phosphorus in soil extracts. Acta Agr. Fenn. 83: 25-47.

KallA, A. 1961. Fertilizer phosphorus in some Finnish soils. J. Scient. Agric. Soc. Finl. 33: 131-139.
In the plots amended annually with $60 \mathrm{~kg}$ of $\mathrm{P}$ per $\mathrm{ha}^{-1}$, the $\mathrm{P}$ addition markedly exceeded the $\mathrm{P}$ withdrawal by yields, estimated on the basis of nutrient uptake data of JAAKKOLA et al. (1982). In many soils the recovery of residual $\mathrm{P}$, however, remained quite small. This may be attributable to the uneven distribution of added $\mathrm{P}$ in soils, owing to the placement of fertilizers in bands. The uneven distribution, in turn, was reflected in the large variation between replicates, which decreased the statistical significance of the observed changes.

Acknowledgement. The author wishes to thank Prof. Paavo Elonen and Dr. Into Saarela, Agricultural Research Centre, and the staff of the research stations for their help in collecting the soil samples. Financial support by the Academy of Finland is gratefully acknowledged.

KaILA, A. 1963. Fertilizer phosphorus in various fractions of soil phosphorus. J. Scient. Agric. Soc. Finl. 35: $36-46$.

KAILA, A. 1964. Fractions of inorganic phosphorus in Finnish mineral soils. J. Scient. Agric. Soc. Finl. 36: $1-13$.

KAILA, A. 1965. The fate of water-soluble phosphate applied to some mineral soils. J. Scient. Agric. Soc. Finl. 37: 104-115.

KaILA, A. 1969. Residual effect of rock phosphate and superphosphate. J. Scient. Agric. Soc. Finl. 41: $82-88$.

LATURI, R. 1977. Typpi-, fosfori- ja kaliumlannoituksen kehitys Suomessa. Kehittyvă Maatalous 36: 3-10.

SaArela, I. \& Sippol.A, J. 1987. Kalkituksen vaikutus kasvien fosforin saantiin. Koetoiminta ja Käytäntö 44: 52.

Ms received July 25,88 


\section{SELOSTUS}

\section{Pitkäaikaisen superfosfaattilannoituksen}

\section{vaikutus kivennäismaiden fosforitilaan}

I Epäorgaanisen fosforin fraktiomuutokset

\section{Helinä Hartikainen \\ Helsingin yliopisto, Maanviljelyskemian laitos, 00710 Helsinki}

Tutkimuksessa selvitettiin muokkauskerroksen epäorgaanisissa fosforivaroissa tapahtuneita muutoksia pitkäaikaisessa kenttäkokeessa. Maanäytteet oli koottu Maatalouden Tutkimuskeskuksen eri tutkimusasemilla olleista 16 fosforilannoituskokeesta ruuduilta, joita oli viljelty seitsemän vuotta ilman fosforilannoitusta tai joille oli vuosittain annettu 30 tai $60 \mathrm{~kg} \mathrm{P}: \mathrm{a} \mathrm{ha} \mathrm{h}^{-1}$ superfosfaattina. Vertailunāytteet oli otettu koekentiltă ennen kokeiden perustamista.

Rinnakkaisnäytteiden suuren hajonnan vuoksi käsittelyjen văliset erot eivät aina olleet tilastollisesti merkitseviä. Voitiin kuitenkin arvioida, että raudan ja aluminiumin sitomaksi oletetut fosforireservit vähenivät lan- noittamattomissa savimaissa $22-69$ ja karkeammissa kivennäismaissa $8-140 \mathrm{~kg} \mathrm{ha}^{-1}$. Kalsiumin sitomat varat pienenivăt seitsemässă maassa $16-34 \mathrm{~kg}$. Lannoitetuissa koeruuduissa oli yleensä havaittavissa fosforin kertymistä raudan ja aluminiumin sitomaan fraktioon: pienemmän lannoitemäärän (yhteensä $210 \mathrm{~kg}$ ) aiheuttama kertymä hehtaaria kohti oli savimaissa 33-109 ja suuremman (yhteensă $420 \mathrm{~kg}$ ) $75-225 \mathrm{~kg}$. Vastaavat muutokset karkeampien kivennäismaiden fosforivaroissa olivat $2-174$ ja 46-368 kg. Mitä suurempia lannoitemäärät olivat, sitä suurempi osa maahan kertyneestả fosforista năytti pidättyneen aluminiumin sitomaan fraktioon. 